\title{
RELASI.

\section{Pengaruh Marketing Mix Terhadap Keputusan Menabung Dengan Reputasi Sebagai Variabel Intervening Pada Bank BNI KCP. Univ. Jember}

\author{
Alfiatin $^{1}$, Yuniorita Indah Handayani ${ }^{2,}$ Muhaimin Dimyati ${ }^{3}$ \\ Sekolah Tinggi Ilmu Ekonomi Mandala, Jember \\ Email: yuniorita@stie-mandala.ac.id ${ }^{2}$, dimyati@stie-mandala.ac.id ${ }^{3}$
}

\begin{abstract}
This study aims to examine whether there is a product, price, place and promotion influence on saving decisions through reputation as an intervening variable. The population in this study are bank customers who have joined more than one month to more than two years BNI kcp Bank. Univ. Jember The sampling technique in this study uses the accidental sampling approach. The number of samples is 100 respondents. The analysis method used is the path analysis method using SPSS 22 software. The results of this study show that the marketing mix has an effect on reputation, and reputation has an effect on saving decisions. Products, prices and promotions affect the decision to save while the place / location has no effect on the decision to save. From the results of the path analysis, reputation is only able to be an intervening variable on the place / location variable on saving decisions. Keywords: Product, Price, Place, Promotion, Reputation, Savings Decision
\end{abstract}

\section{Pendahuluan}

Perkembangan perbankan saat ini mengalami peningkatan yang cukup signifikan. Perubahan ini terjadi disebabkan oleh pesatnya pertumbuhan dan perkembangan teknologi, informasi, mesin dan alat-alat berat, terlebih lagi teknologi komunikasi. Akibat dari perubahan yang begitu cepat berimbas pada perubahan perilaku masyarakat. Dengan adanya teknologi, maka masyarakat dapat dengan mudah mendapatkan informasi. Terutama tentang perbankan di indonesia.

Peningkatan dalam sektor perbankan di Indonesia ini terjadi karena beberapa faktor dan salah satunya adalah pemasaran atau marketing, pemasaran yang baik dan benar akan memberikan dampak yang baik pada para pelaku industri salah satunya sektor yang terkena imbas adalah dunia perbankan. Pemasaran bank adalah suatu proses untuk menciptakan dan mempertukarkan produk atau jasa bank yang ditunjukan untuk memenuhi kebutuhan dan keinginan nasabah dengan cara memberikan kepuasan. (Kasmir, 2012) 
Akibat perubahan teknologi yang begitu cepat, berimbas juga kepada perilaku masyarakat. Informasi yang masuk dari berbagai sumber dengan mudah diperoleh dan diserap oleh berbagai masyarakat sekalipun dipelosok pedesaan yang terpencil. Imbas yang paling nyata adalah masyarakat begitu cepat pandai dalam memilih produk yang disukai dengan membanding-bandingkan antara produk yang sejenis, tentu saja dalam arti yang sesuai dengan keinginan dan kebutuhan mereka. Cepatnya informasi yang masuk akibat majunya teknologi sektor informasi seperti televisi, radio, koran atau majalah telah menjadikan masyarakat semakin cerdas dan masyarakat sudah semakin sulit untuk dibohongi. (Kasmir, 2012)

Dengan adanya persaingan antar bank yang semakin ketat ini maka menuntut seorang manajer pemasaran jasa perbankan untuk dapat mengidentifikasi dan menganalisis mengenai perilaku konsumen. Menyikapi hal tersebut, tentunya pelaku bisnis terutama perbankan akan berusaha semaksimal mungkin untuk mempengaruhi perilaku konsumen untuk menjadi mitra maupun konsumen terbaiknya. Pihak perbankan juga dituntut dapat secara jeli memprediksikan perkembangan ekonomi mikro dan makro agar dapat menentukan hasil yang akan dicapai tidak hanya mengoptimalkan pendapatan yang berbasis pelayanan nasabah tetapi bisnis yang berbasis pada pelayanan calon nasabah.

Marketing adalah mengidentifikasi, memenuhi kebutuhan manusia dan sosial. Salah satu definisi yang baik yaitu pemasaran adalah "memenuhi kebutuhan dengan cara mengutungkan”. Marketing Mix (bauran pemasaran) adalah stretegi pemasaran yang menggunakan kombinas empat variable atau kegiatan yang merupakan inti dari sistem pemasaran perusahaan, yaitu : produk, harga, kegiatan promosi, dan sistem distribusi. (Susatya Herlambang, 2014)

Pemenuhan kebutuhan dan keinginan konsumen membutuhkan konsep pemasaran yang disebut dengan bauran pemasan (marketing mix). Menurut Kotler (2009 : 15), markeing mix merupakan kombinasi dari empat variabel penting dari konsep pemasaran yang dapat dikendalikan oleh perusahaan. Empat varibel 
tersebut meliputi produk (produk), harga (price), tempat (place) dan promosi (promotion), dan biasanya disingkat dengan 4P.

Produk sebagai sesuatu yang dapat ditawarkan ke pasar untuk mendapatkan perhatian untuk dibeli, untuk digunakan atau dikonsumsi yang dapat memenuhi keinginan dan kebutuhan. Produk merupakan keseluruhan konsep objek atau proses yang memberikan sejumlah nilai manfaat kepada konsumen. Produk dalam penelitian ini meliputi : Memenuhi kebutuhan pelanggan, memenuhi keinginan pelanggan dan variasi produk.

Harga merupakan salah satu aspek penting dalam kegiatan marketing mix. Penentuan harga menjadi sangat penting untuk diperhaikan, megingat harga sangat menentukan laku tidaknya produk dan jasa perbankan. Harga dalam penelitian ini meliputi : biaya administrasi yang rendah dan saldo minimal pembukaan rekening.

Lokasi berarti berhubungan dengan dimana perushaan harus bermarkas dan melakukan opersi. Penentuan lokasi bagi perbankan lebih ditekankan kepada lokasi cabang. Penentuan lokasi sangat penting mengingat apabila salah dalam menganalisis akan berakibat meningkatnya biaya yang akan dikeluarkan nantinya. Lokasi yang tidak strategis akan mengurangi minat nasabah untuk berhubungan dengan bank. Lokasi dalam penelitian ini meliputi : Lokasi yang strategis, fasilitas yang disediakan dan kemudah untuk alat transportasi.

Promosi merupakan kegiatan marketing mix yang terakhir. Dalam kegiatan setiap bank berusaha untuk mempromosikan seluruh produk dan jasa yang dimiliki baik langsung maupun tidak langsung. Promosi yang di maksud dalam penelitian ini adalah informasi melalui website, pelayanan custimer service dan hadiah yang ditawarkan.

Apabila perusahaan tidak mampu mengkombinasikan marketing mix, sebagai implikasi yang nyata kedepan, maka akan berdampak pada eksistensi perusahaan perbankan itu sendiri. Nasabah dan calon nasabah tidak percaya lagi untuk menyimpan uangnya pada perusahaan kita dan akan beralih ke perusahaan lain yang lebih terpercaya. 
Reputasi perusahaan merupakan salah satu unsur terpenting dalam dunia bisnis. Sebab baik buruknya dalam reputasi perusahaan merupakan indikator penting dari keberhasilan perusahan tersebut. Reputasi perusahaan menjadi salah satu pegangan bagi banyak orang dalam mengambil berbagai macam keputusan penting. Contoh, keputusan tersebut adalah membeli barang atau jasa yang dihasilakn perusahaan, berlangganan, dan merekomendasikan produk perusahaan kepada orang lain, sehingga mau tidak mau perusahaan mempunyai reputasi dimasyarakat. Reputasi dalam penelitian ini adalah : Bank memiliki nama baik, dikenal luas dan sebutan untuk bank itu sendiri.

Keputusan pembelian yang dilakukan oleh konsumen terhadap suatu produk merupakan konsep yang sangat penting dalam konsidi persaingan yang semakin ketat. Salah satunya faktor yang dapat mempengaruhi keputusan pembelian adalah reputasi perusahaan (Van Oostenbrugge, 2013). Keputusan dalam membeli serta memilih sebuah produk, tergantung dengan adanya kepercayaan yang dimiliki oleh konsumen terhadap perusahaan dalam menciptakan produk yang sesuai dengan keinginan serta kebutuhan konsumen sebagai dasar untuk membuat suatu keputusan dalam melakukan pembalian.

Berdasarkan latar belakang di atas, alasan mengapa dilakukan penelitian ini di latar belakangi masalah dari marketing mix (bauran pemasaran, persaingan yang ketat antara Bank BNI dengan bank Konvensianal maupun bank Syariah, diperkuat dengan reputasi bank agar dalam benak nasabah terciptanya persepsi dan keyakinan positif terhadap produk Bank BNI kcp. Univ. Jember yang berpengaruh terhadap keputusan.

\section{Hipotesis}

Berdasarkan kerangka berfikir, penelitian relevan terdahulu, teori di atas maka hipotesis dalam penelitian ini adalah sebagai berikut:

1. Apakah Produk berpengaruh terhadap Reputasi

2. Apakah Harga berpengaruh terhadap Reputasi

3. Apakah Lokasi/Tempat berpengaruh terhadap Reputasi

4. Apakah Promosi berpengaruh terhadap Reputasi

\section{STIE MANDALA JEMBER}


5. Apakah Reputasi berpengaruh terhadap Keputusan Menabung

6. Apakah Produk berpengaruh terhadap Keputusan Menabung

7. Apakah Harga berpengaruh terhadap Keputusan Menabung

8. Apakah Lokasi/Tempat berpegaruh terhadap Keputusan Menabung

9. Apakah Promosi berpengaruh terhadap Keputusan Menabung

10. Apakah Reputasi memediasi antara Maketing Mix terhadap Keputusan Menabung

\section{Metode Penelitian}

Penelitian ini dilakukan pada Bank BNI kcp Univ. Jember yang berlokasi di Jl. Kalimantan I/60 Jember, Jawa Timur.

Populasi dalam penelitian ini adalah nasabah bank yang sudah bergabung lebih dari satu bulan sampai dengan lebih dari dua tahun Bank BNI kcp. Univ. Jember.

Menurut Ferdinan (2014 : 173) mengatakan bahwa ukuran sampel yang lebih besar dari 30 dan kurang dari 500 sudah memadai bagi kebanyakan penelitian. Dalam penelitian multivariate

(termasuk yang menggunakan analisis regresi multivariat) besarnya sampel ditentukan sebanyak 25 kali variabel independen. Analisis regresi dengan 4 variabel independen membutuhkan kecukupan sampel sebanyak 100 sampel responden. Sampel dalam penelitian ini sebanyak 100 sampel.

Teknik pengambilan sempel dalam penelitian ini menggunakan pendekatan accidental sampling, yang dilakukan dengan cara memberikan koesioner kepada nasabah yang ditemui dan bersedia mengisi koesioner.

\section{A. Metode Analisis Data}

Metode analisis data yang digunakan dalam penelitian ini adalah regresi linier berganda yaitu dengan:

\section{Uji Validitas}

Uji validitas digunakan untuk mengukur valid tidaknya suatu alat ukur, digunakan pendekatan secara statistika, yaitu melalui nilai koefisien korelasi skor butir pertanyaa dengan skor total. Skor tersebut dikatakan valid apabila 
kurang dari taraf nilai signifikansi 0,05.

\section{Uji Reliabilitas}

Uji Reabilitas sebenarnya adalah alat untuk mengukur kuesioner yang merupakan indikator dari variabel atau konstruk. Suatu kuesioner dikatakan reliabel atau handal jika jawaban seseorang terhadap pernyataan dalah kuesioner atau stabil dari waktu kewaktu. SPSS memberikan fasilitas untuk mengukur reliabilitas dengan uji statistic Cronbach Alpha $(\alpha)$. Suatu kontruk atau variabel dikatakan reliabel jika memberikan nilai Cronbach Alpha >0,60 rendah.

\section{B. Uji Asumsi Klasik}

Uji asumsi klasik digunakan lebih dahulu untuk menguji hipotesis. Dimana Uji uji asumsi klasik dilakukan dengan menggunakan alat uji statistik, yaitu :

\section{1) Uji Normalitas}

Uji normalitas digunakan untuk menguji apakah model dalam regresi, variabel terikat dan variabel bebas keduanya mempunyai distribusi normal atau tidak.

\section{2) Uji Multikolinieritas}

Uji multikolinieritas bertujuan untuk menguji apakah model regresi ditemukan adanya korelasi antar variabel bebas (Independen). Model regresi yang baik seharusnya tidak terjadi korelasi diantara variable independent. Jika variabel independent saling berkorelasi, maka variabel variabel ini tidak ortogonal. Untuk mengetahui ada atau tidak multikolinieritas dapat dilihat dari nilai tolerance dan lawannya, variance inflation factor (VIF).

\section{3) Uji Heteroskedastisitas}

Uji heterokedastisitas bertujuan menguji apakah dalam model regresi terjadi ketidaksamaan variance dari residual satu pengamatan kepengamatan lain. Jika variance dari residual satu pengamatan ke pengamatan yang lain tetap, maka disebut dengan Homoskedastisitas dan jika berbeda disebut 
Heterokedastisitas. Model regresi yang baik adalah yang Homoskedastisitas atau tidak terjadi Heterokedastisitas. Uji ini dapat dilakukan menggunakan uji Glejser, dimana jika signifikan > 0,05, maka tidak terjadi gejala heteroskedastisitas dan sebaliknya.

\section{Analisis Jalur/Path Analysis}

Analisis jalur ini bertujuan untuk mengetahui pengaruh langsung dan tidak langsung, secara simultan atau parsial beberapa variabel eksogenus terhadap sebuah variabel endogenus. Metode yang digunakan dalam penelitian ini adalah path analysis atau analisis jalur dengan menggunakan korelasi dan regresi sehingga dapat diketahui untuk sampai pada variabel dependen terakhir, harus melalui jalur langsung atau melalui variabel intervening, (Sugiyono, 2017). Analisis jalur adalah sebuah metode untuk mempelajari efek langsung (direct effect) maupun efek tidak langsung (indirect effect) dari variabel. Dalam penghitungan digunakan jasa komputer berupa software dengan program SPSS For Windows Versi 22.

Rumus analisis jalur dalam penelitian ini adalah sebagai berikut :

1) Pengaruh variabel independent produk $\left(X_{1}\right)$, harga $\left(X_{2}\right)$, tempat $\left(X_{3}\right)$ dan Promosi $\left(\mathrm{X}_{4}\right)$ terhadap reputasi $\left(\mathrm{Y}_{1}\right)$. Rumusnya adalah :

$$
\mathrm{Y}_{1}=\mathrm{PY}_{1} \mathrm{X}_{1}+\mathrm{PY}_{1} \mathrm{X}_{2}+\mathrm{PY}_{1} \mathrm{X}_{3}+\mathrm{PY}_{1} \mathrm{X}_{4}+\mathrm{e}
$$

2) Pengaruh variabel independent produk $\left(X_{1}\right)$, harga $\left(X_{2}\right)$, tempat $\left(X_{3}\right)$, Promosi $\left(\mathrm{X}_{4}\right)$ dan reputasi $\left(\mathrm{Y}_{1}\right)$ terhadap keputusan menabung $\left(\mathrm{Y}_{2}\right)$. Rumusnya adalah: $\mathrm{Y}_{2}=\mathrm{PY}_{2} \mathrm{X}_{1}+\mathrm{PY}_{2} \mathrm{X}_{2}+\mathrm{PY}_{2} \mathrm{X}_{3}+\mathrm{PY}_{2} \mathrm{X}_{4}+\mathrm{PY}_{2} \mathrm{Y}_{2}+\mathrm{e}$

3) Pengaruh tidak langsung variabel independent produk, harga, tempat dan promosi terhadap keputusan menabung melalui variabel intervening reputasi. (Ghozali, 2016). Rumusnya adalah sebagai berikut:

a. Pengaruh tidak langsung / indirect effect, (X) terhadap keputusan menabung $\left(\mathrm{Y}_{2}\right)$ melalui reputasi $\left(\mathrm{Y}_{1}\right)$. Rumusnya adalah :

Pengaruh langsung $\mathrm{X}_{1}$ ke $\mathrm{Y}_{2}=\mathrm{p} 1$

Pengaruh tak langsung $\mathrm{X} 1$ ke $\mathrm{Y}_{1}$ ke $\mathrm{Y}_{2}=\mathrm{p} 2 \mathrm{xp} 3$ 
Total pengaruh $($ Total Effect $)=\mathrm{p} 1+(\mathrm{p} 2 \times \mathrm{p} 3)$

\section{Uji Hipotesis}

\section{a. Uji t}

Uji ini dilakukan untuk mengetahui apakah masing-masing variabel secara sendiri-sendiri berpengaruh secara signifikan terhadap variabel terikat. Uji statistik t pada dasarnya menunjukan seberapa jauh pengaruh satu variabel penjelas atau independent secara individual dalam menerangkan variasi variabel dependen. Hipotesis nol (Ho) yang hendak diuji adalah apakah suatu parameter (bi) sama dengan nol, atau b.Ho : bi $=0$

Artinya apakah suatu variabel independent bukan merupakan penjelas yang signifikan terhadap variabel dependen. Hipotesis alternative (Ha) parameter suatu variabel tidak sama dengan nol, atau : c.Ha : bi $\neq 0$

Artinya variabel tersebut merupakan penjelasan yang signifikan terhadap variabel dependen. (Ghozali, 2016:97) Apabila suatu hipotesisi alternative diterima jika jumlah degree os freedom (df) adalah $\quad 20 \quad$ atau lebih, dan derajat kepercayaan sebesar 5\%, maka Ho yang menyatakan bi $=0$ dapat ditolak bila nilai $\mathrm{t}$ lebih besar dari 2 (dalam nilai absolut). Membandingkan nilai statistic t dengan titik kritis menurut table. Apabila nilai $\mathrm{t}$ hasil perhitungan lebih tinggi dibandingkan nilai table, maka hipotesis dapat diterima. (Ghozali, $2016: 97$ )

\section{b. Koefisien Koefisien Determinasi (Adjusted $\mathbf{R}^{\mathbf{2}}$ )}

Koefisien determinasi $\left(\mathrm{R}^{2}\right)$ pada intinya mengukur seberapa juah kemampuan model dalam menerangkan variasi variabel dependen. Nilai koefisien determinasi adalah antara nol dan satu. Nilai $\mathrm{R}^{2}$ yang kecil berarti kemampuan variabel-variabel independent dalam menjelaskan variasi variabel dependen amat terbatas. Secara umum koefisien determinasi untuk data silang (crossection) relative rendah karena adanya variasi yang besar antara masig-masing pengamatan, sedangkan untuk data runtun waktu (time series) biasanya mempunyai nilai koefisien deteminasi yang tinggi. (Ghozali, 2016) 


\section{Hasil Dan Pembahasan}

\section{Analisis Uji Validasi}

Berdasarkan uji validasi diketahui hasil perbandingan antara $\mathrm{r}_{\text {hitung }}$ yang merupakan koefisien korelasi dengan $\mathrm{r}_{\text {ketetapan }}$ yang menunjukkan bahwa semua $\mathrm{r}_{\text {hitung }}$ lebih besar. Dengan demikian dapat diambil kesimpulan bahwa semua item pernyataan dalam kuisioner adalah valid. Yang artinya variabel tersebut mampu mengukur aspek yang sama atau apa yang ingin diukur oleh peneliti.

\section{Analisis Uji Reliablity}

Berdasarkan uji reliability diketahui nilai $\alpha \mathrm{p}$ variabel $>$ dari nilai kritis reliabilitas. Variabel produk $\left(\mathrm{X}_{1.1}\right)$ 0,778>0,60, $\left(\mathrm{X}_{1.2}\right) \quad 0,769>0,60$, $\left(X_{1.3}\right)$ 0,769>60, Harga $0,771>0,60 \quad\left(X_{2 \cdot 1}\right), 0,770>0,60\left(X_{2 \cdot 2}\right), 0,802>0,60$ $\left(\mathrm{X}_{2.3}\right)$, Tempat $\quad\left(\mathrm{X}_{3.1}\right) \quad 0,768>0,60, \quad\left(\mathrm{X}_{3.2}\right)$ 0,763>0,60, $\left(\mathrm{X}_{3.3}\right)$ 0,676>0,60, Promosi $\left(\mathrm{X}_{4.1}\right)$ 0,775>0,60, $\left(\mathrm{X}_{4.2}\right)$ 0,769>0,60, $\left(\mathrm{X}_{4.3}\right)$ 0,797>0,60, Reputasi $\left(\mathrm{Y}_{1.1}\right)$ 0,769>0,60, ( $\left.\mathrm{Y}_{1.2}\right)$ 0,766>0,60, ( $\left.\mathrm{Y}_{1.3}\right) \quad$ 0,799>0,60, Keputusan Menabung ( $\left.\mathrm{Y}_{2.1}\right)$ $0,800>0,60,\left(\mathrm{Y}_{2.2}\right)$ 0,779>0,60, $\left(\mathrm{Y}_{2.3}\right)$ 0,774>0,60. Berdasarkan hasil perhitungan di atas maka bisa ditarik kesimpulan bahwa semua item pernyataan dalam kuisioner dapat dipercaya sebab hasil pengukuran relatif konsisten. Meskipun pernyataan tersebut diberikan dua kali atau lebih pada responden yang berbeda sehingga kuisioner ini dapat digunakan untuk penelitian selanjutnya.

\section{Uji Asumsi Klasik}

\subsection{Uji Normalitas}

Uji normalitas digunakan untuk menguji data variabel independen dan dependen pada persamaan regresi yang dihasilkan apakah terdistribusi normal atau tidak normal. Data variabel dinyatakan terdistribusi normal jika memiliki nilai signifikansi > 0,05. Uji normalitas dapat dilakukan dengan uji analisis statistic dengan melihat tabel One-Sampel Kolmogorov-Smirnow. Berdasarkan hasil menunjukkan nilai sebesar 0,200 yaitu lebih besar dari tingkat signifikan 0,05. Dari uji di atas diketahui model regresi untuk jalur pertama dan kedua mempunyai nilai lebih dari 5\%. Maka dapat dapat disimpulkan bahwa model 
regresi untuk jalur pertama dan jalur dua terdistrubisi normal.

\subsection{Uji Multikolinearitas}

Uji multikolinearitas bertujuan untuk mengetahui ada tidaknya hubungan linear yang sempurna diantara variabel-variabel bebas dalam regresi. Untuk mengetahui ada tidaknya gejala multikolinearitas dapat dilihat dari besarnya nilai tolerance dan VIF (Varians Inflation Factor) melalui program SPSS. Berdasarkan uji Multikolinearitas diketahui nilai tolerance variabel Produk 0,668, nilai VIF 1,498. Nilai tolerance variabel Harga 0,863, nilai VIF 1,158. Nilai tolerance variabel Tempat 0,618 nilai VIF 1,618. Nilai tolerance variabel Promosi 0,658, nilai VIF 1,510. Nilai tolerance variable Keputusan Menabung 0,731, nilai VIF 1,369. Dari uji di atas diketahui model regresi untuk jalur pertama dan kedua mempunyai nilai VIF di sekitar angka 1 dan nilai tolerance mendekati angka 1. Maka dapat dapat disimpulkan bahwa model regresi untuk jalur pertama dan jalur dua tidak terjadi gejala multikolinieritas.

\subsection{Uji Heteroskedastisitas}

Heteroskedastisitas bertujuan untuk menguji apakah dalam model regresi terjadi ketidaksamaan variance dan residual satu pengamatan ke pengamatan yang lain. Uji ini dapat dilakukan menggunakan uji Glejser, dimana jika signifikansi > 0,05, maka tidak terjadi gejala heteroskedastisitas dan sebaliknya. Berdasarkan hasil menunnjukan nilai sebesar 0,234 lebih besar dari 0,05 sehingga dapat disimpulkan bahwa untuk jalur pertama dan kedua tidak terdapat masalah atau gejala heteroskedastisitas. Artinya model regresi yang dipakai untuk penelitian ini layak dilakukan.

\section{Analisis Jalur}

Proses perhitungan koefisien jalur dalam penelitian ini menggunakan software SPSS Versi 22. Nilai koefisien jalur ditunjukan oleh nilai output SPSS yang dinamakan Coefficient dan dinyatakan sebagai Standardized Coeffitient atau dikenal dengan nilai Beta. Koefisien jalur dalam model struktural perlu diuji signifikansinya sehingga dapat diperoleh koefisien jalur yang tidak signifikan dan koefisien jalur yang signifikan.

\section{STIE MANDALA JEMBER}


Koefisien jalur yang tidak signifikan dapat dihilangkan/dihapus dengan menerapkan model trimming. Hasil dari pengujian koefisien jalur tersebut digunakan untuk menjawab hipotesis penelitian yang dirumuskan. Hasil pengujian koefisien jalur (path coefficient) pengaruh langsung disajikan pada Tabel 1.

\section{Tabel 1. Koefisien Pengaruh Langsung Reputasi}

\begin{tabular}{|c|c|c|c|c|c|c|}
\hline \multicolumn{7}{|c|}{ Coefficients $\mathrm{a}^{\mathrm{a}}$} \\
\hline \multicolumn{4}{|c|}{$\begin{array}{c}\text { Unstandardized } \\
\text { Coefficients }\end{array}$} & \multirow{2}{*}{$\begin{array}{c}\text { Standardized } \\
\text { Coefficients } \\
\text { Beta }\end{array}$} & \multirow[b]{2}{*}{$\mathrm{t}$} & \multirow[b]{2}{*}{ Sig. } \\
\hline \multicolumn{2}{|c|}{ Model } & $\mathrm{B}$ & Std. Error & & & \\
\hline & (Constant) & 5.105 & 1.233 & & 4.141 & .000 \\
\hline & Produk & .245 & .090 & .280 & 2.708 & .008 \\
\hline & Harga & .060 & .072 & .078 & .830 & .409 \\
\hline & Tempat & .066 & .078 & .094 & .846 & .400 \\
\hline & Promosi & .213 & .100 & .226 & 2.145 & .035 \\
\hline
\end{tabular}

Tabel menunjukkan bahwa jalur dari variabel Produk, Harga, Tempat dan Promosi terhadap variabel Reputasi searah, dapat disimpulkan bahwa produk yang beraneka ragam, biaya administrasi yang rendah, lokasi yang nyaman, dan promosi yang membuat kebutuhan pelanggan terpenuhi akan meningkatkan reputasi dikalangan masyarakat.

Tabel 2. Koefisien Pengaruh Langsung Keputusan Menabung

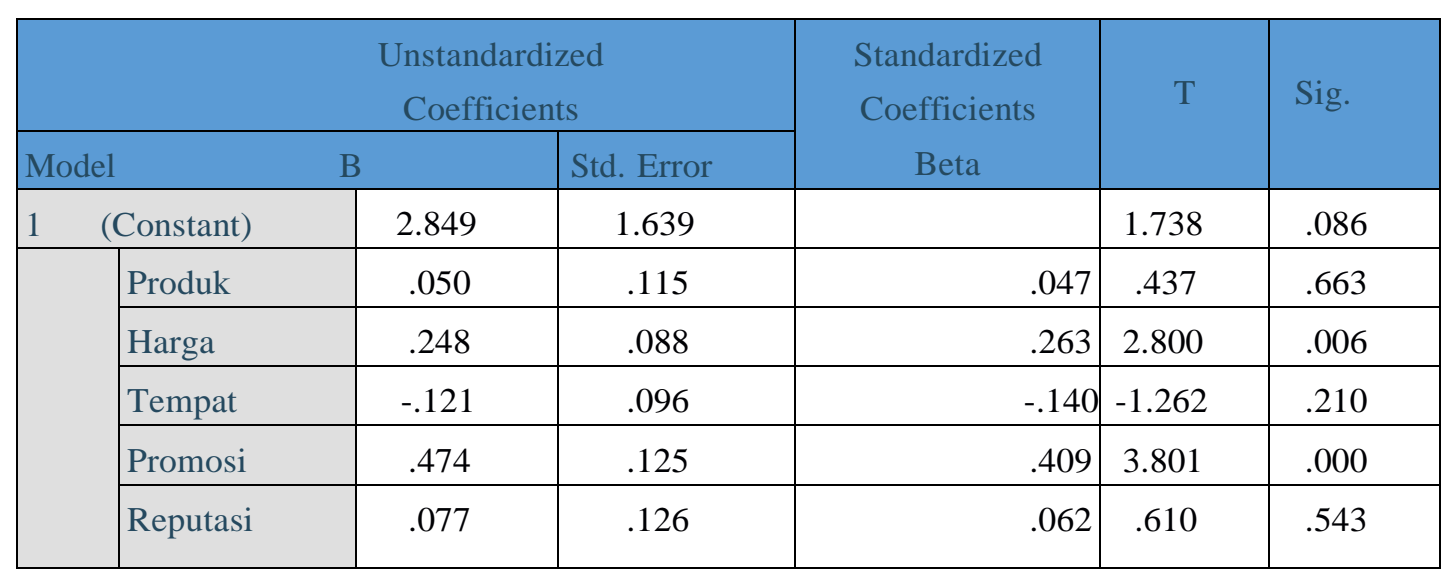

Tabel menunjukkan bahwa jalur dari variabel Reputasi, Produk, Harga, dan Promosi terhadap variabel Keputusan Menabung searah, dapat disimpulkan bahwa reputasi 
yang baik, dikenal luas dan mudah diingat, produk yang bervariasi, saldo minimum yang diberikan pada saat pembukaan rekening, dan promosi melalui website akan mempengaruhi keputusan nasabah dalam menabung.

\section{1) Pengujian Hipotesis ke-1 Produk $\left(\mathbf{X}_{1}\right)$ Terhadap Reputasi $\left(\mathbf{Y}_{1}\right)$}

Hipotesis pertama menyatakan terdapat pengaruh signifikan Produk terhadap Reputasi nasabah bank BNI kcp. Univ. Jember. Berdasarkan hasil pengujian koefisien jalur pada tabel 1 menunjukkan nilai t-hitung sebesar 2,708 dengan tingkat signifikan sebesar 0.008 , artinya produk mempunyai pengaruh dan signifikan terhadap reputasi. Sehingga Ha diterima dan Ho ditolak. Disimpulkan bahwa variabel Produk berpengaruh signifikan terhadap Reputasi. Hipotesis pertama terbukti atau diterima. Artinya variabel Produk berpengaruh secara signifikan terhadap Reputasi nasabah bank BNI kcp. Univ. Jember.

\section{2) Pengujian Hipotesis ke-2 Harga (X2) terhadap Reputasi (Y1)}

Hipotesis kedua menyatakan terdapat pengaruh signifikan Harga terhadap Reputasi nasabah bank BNI KCP. Univ. Jember. Berdasarkan hasil pengujian koefisien jalur pada tabel 1 menunjukkan nilai t-hitung sebesar 0,830 dengan tingkat signifikan sebesar 0,409, artinya harga mempunyai pengaruh namun tidak signifikan terhadap reputasi. Sehingga Ho diterima dan Ha ditolak. Disimpulkan bahwa harga berpengaruh namun tidak signifikan terhadap reputasi. Hipotesis kedua tidak terbukti atau ditolak. Artinya variabel Harga tidak berpengaruh secara signifikan terhadap Reputasi nasabah bank BNI kcp. Univ. Jember.

\section{3) Pengujian Hipotesis ke-3 Lokasi $\left(\mathrm{X}_{3}\right)$ terhadap Reputasi ( $\left.\mathrm{Y}_{1}\right)$}

Hipotesis ketiga menyatakan terdapat pengaruh signifikan Tempat/Lokasi terhadap Reputasi nasabah bank BNI kcp. Univ. Jember. Berdasarkan hasil pengujian koefisien jalur pada tabel 1 menunjukkan nilai t-hitung sebesar 0,846 dengan tingkat signifikan sebesar 0,400, artinya tempat/lokasi mempunyai pengaruh namun tidak signifikan terhadap reputasi. Sehingga Ho diterima dan $\mathrm{Ha}$ ditolak. Disimpulkan bahwa tempat berpengaruh namun tidak signifikan terhadap reputasi. Hipotesis ketiga tidak terbukti atau ditolak. Artinya variabel Tempat/Lokasi tidak berpengaruh secara signifikan terhadap Reputasi nasabah 
bank BNI kcp. Univ. Jember.

\section{4) Pengujian Hipotesis ke-4 Promosi $\left(\mathbf{X}_{4}\right)$ terhadap Reputasi ( $\left.\mathbf{Y}_{1}\right)$}

Hipotesis keempat menyatakan terdapat pengaruh signifikan Promosi terhadap Reputasi nasabah bank BNI kcp. Univ. Jember. Berdasarkan hasil pengujian koefisien jalur pada tabel 1 menunjukkan nilai t-hitung sebesar 2,145 dengan tingkat signifikan sebesar 0.035 , artinya produk mempunyai pengaruh dan signifikan terhadap reputasi. Sehingga Ha diterima dan Ho ditolak. Disimpulkan bahwa variabel Produk berpengaruh signifikan terhadap Reputasi. Hipotesis keempat terbukti atau diterima. Artinya variabel Promosi berpengaruh secara signifikan terhadap Reputasi nasabah bank BNI kcp. Univ. Jember.

\section{5) Pengujian Hipotesis ke-5 Reputasi (Y1) terhadap Keputusan Menabung $\left(\mathbf{Y}_{2}\right)$}

Hipotesis kelima menyatakan terdapat pengaruh signifikan Reputasi terhadap Keputusan Menabung nasabah bank BNI KCP. Univ. Jember. Berdasarkan hasil pengujian koefisien jalur pada tabel 2 menunjukkan nilai t-hitung sebesar 0,610 dengan tingkat signifikan sebesar 0,543 , artinya reputasi mempunyai pengaruh namun tidak signifikan terhadap keputusan menabung. Sehingga Ho diterima dan Ha ditolak. Disimpulkan bahwa reputasi berpengaruh namun tidak signifikan terhadap keputusan menabung. Hipotesis kelima tidak terbukti atau ditolak. Artinya variabel reputasi tidak berpengaruh secara signifikan terhadap keputusan menabung nasabah bank BNI kcp. Univ. Jember.

\section{6) Pengujian Hipotesis ke-6 Produk (X1) terhadap Keputusan Menabung ( $\mathbf{Y}_{2}$ )}

Hipotesis keenam menyatakan terdapat pengaruh signifikan Produk terhadap Keputusan Menabung nasabah bank BNI kcp. Univ. Jember. Berdasarkan hasil pengujian koefisien jalur pada tabel 2 menunjukkan nilai t-hitung sebesar 0,437 dengan tingkat signifikan sebesar 0,663 , artinya produk mempunyai pengaruh namun tidak signifikan terhadap keputusan menabung. Sehingga Ho diterima dan Ha ditolak. Disimpulkan bahwa produk berpengaruh namun tidak signifikan terhadap keputusan menabung. Hipotesis keenam tidak terbukti atau ditolak. Artinya variabel produk tidak berpengaruh secara signifikan terhadap keputusan 
menabung nasabah bank BNI kcp. Univ. Jember.

7) Pengujian Hipotesis ke-7 Harga $\left(\mathrm{X}_{2}\right)$ terhadap Keputusan Menabung $\left(\mathrm{Y}_{2}\right)$

Hipotesis ketujuh menyatakan terdapat pengaruh signifikan Harga terhadap Keputusan Menabung nasabah bank BNI kcp. Univ. Jember. Berdasarkan hasil pengujian koefisien jalur pada tabel 2 menunjukkan nilai thitung sebesar 2,800 dengan tingkat signifikan sebesar 0.006, artinya harga mempunyai pengaruh dan signifikan terhadap keputusan menabung. Sehingga Ha diterima dan Ho ditolak. Disimpulkan bahwa variabel harga berpengaruh signifikan terhadap keputusan menabung. Hipotesis ketujuh terbukti atau diterima. Artinya variabel harga berpengaruh secara signifikan terhadap keputusan menabung nasabah bank BNI kcp. Univ. Jember.

\section{8) Pengujian hipotesis ke-8 Tempat $\left(\mathrm{X}_{3}\right)$ terhadap Keputusan Menabung $\left(\mathrm{Y}_{2}\right)$}

Hipotesis keenam menyatakan terdapat pengaruh signifikan Tempat terhadap Keputusan Menabung nasabah bank BNI kcp. Univ. Jember. Berdasarkan hasil pengujian koefisien jalur pada tabel 2 menunjukkan nilai thitung sebesar -1,262 dengan tingkat signifikan sebesar 0,210, artinya tempat mempunyai pengaruh dan tidak signifikan terhadap keputusan menabung. Sehingga Ho diterima dan Ha ditolak. Disimpulkan bahwa tempat tidak berpengaruh dan tidak signifikan terhadap keputusan menabung. Hipotesis kedelapan tidak terbukti atau ditolak. Artinya variabel tempat tidak berpengaruh secara signifikan terhadap keputusan menabung nasabah bank BNI kcp. Univ. Jember.

\section{9) Pengujian hipotesis ke-9 Promosi (X4) terhadap Keputusan Menabung ( $\left.\mathbf{Y}_{2}\right)$}

Hipotesis ketujuh menyatakan terdapat pengaruh signifikan Promosi terhadap Keputusan Menabung nasabah bank BNI kcp. Univ. Jember. Berdasarkan hasil pengujian koefisien jalur pada tabel 2 menunjukkan nilai thitung sebesar 3,801 dengan tingkat signifikan sebesar 0.000, artinya promosi mempunyai pengaruh dan signifikan terhadap keputusan menabung. Sehingga $\mathrm{Ha}$ diterima dan Ho ditolak. Disimpulkan bahwa variabel promosi berpengaruh 
signifikan terhadap keputusan menabung. Hipotesis kesembilan terbukti atau diterima. Artinya variabel promosi berpengaruh secara signifikan terhadap keputusan menabung nasabah bank BNI kcp. Univ. Jember.

Tabel 3. Hasil Analisis pengaruh tidak langsung

\begin{tabular}{|c|l|c|c|c|c|l|}
\hline No & Variabel & Direct & Indirect & Total & \multicolumn{1}{|c|}{ Hasil } & \multicolumn{1}{|c|}{ Kesimpulan } \\
\hline 1. & Produk & 0,047 & 0,01736 & 0,06436 & $\begin{array}{l}\text { Direck > indirect } \\
\text { bukan } \\
\text { intervening }\end{array}$ & $\begin{array}{l}\text { Reputasi bukan sebagai } \\
\text { variabel intervening }\end{array}$ \\
\hline 2. & Harga & 0,263 & 0,004836 & 0,267836 & $\begin{array}{l}\text { Direck > indirect } \\
\text { bukan } \\
\text { interveni }\end{array}$ & $\begin{array}{l}\text { Reputasi bukan sebagai } \\
\text { variabel intervening }\end{array}$ \\
\hline 3. & Tempat & $-0,140$ & 0,005828 & $-0,134172$ & $\begin{array}{l}\text { Indirect > direct } \\
=\text { Intervening }\end{array}$ & $\begin{array}{l}\text { Reputasi variabel intervening } \\
\text { variang }\end{array}$ \\
\hline 4. & Promosi & 0,409 & 0,014012 & 0,423012 & $\begin{array}{l}\text { Direck > indirect } \\
\text { bukan } \\
\text { intervening }\end{array}$ & $\begin{array}{l}\text { Reputasi bukan sebagai } \\
\text { variabel intervening }\end{array}$ \\
\hline
\end{tabular}

\section{INTERPRESTASI}

Pada pembahasan ini akan diuraikan interpretasi dari hasil analisis data yang telah disajikan sebelumnya. Berdasarkan hasil penelitian 100 nasabah bank BNI kcp. Univ. Jember sebagian besar responden memberikan jawaban yang cukup baik. Diskripsi atas indikator variabel yang diteliti ini, memberikan informasi tentang tinggi atau rendahnya variabel tersebut dalam mempengaruhi Reputasi dan Keputusan Menabung nasabah bank BNI kcp. Univ. Jember. Pembahasan pada hipotesis yang diajukan dalam penelitian adalah sebagai berikut:

\section{Pengaruh Produk terhadap Reputasi nasabah bank BNI kcp. Univ. Jember}

Berdasarkan hasil analisis yang dilakukan menunjukkan bahwa produk berpengaruh positif dan signifikan terhadap reputasi. Produk yang terdiri dari tiga item yaitu produk yang ditawarkan, informasi produk yang diberikan kepada nasabah dan variasi produk mendapatkan tanggapan yang bagus dari responden bank BNI kcp. Univ. Jember. Rata-rata responden memberikan penilaian yang baik dan positif terhadap produk yang ditawarkan oleh bank, sehingga bisa disimpulkan bahwa semakin banyak produk yang ditawarkan, produk beraneka ragam dan 
variasi produk yang banyak maka akan semakin meningkatkan reputasi bank. Penelitian ini konsisten dengan penelitian yang dilakukan Cristian (2016), Dendawijaya (2009) Kartikasari (2008). Dari kajian teori dan kajian empiris tersebut dapat disimpulkan bahwa hasil dari penelitian ini mengidentifikasi bahwa semakin baik kualitas produk, produk yang beragam dan varian produk yang banyak, maka akan semakin meningkatkan reputasi perusahaan bank BNI kcp. Univ Jember

\section{Pengaruh Harga terhadap Reputasi nasabah bank BNI kcp. Univ. Jember}

Berdasarkan hasil dari analisis yang dilakukan menunjukkan bahwa harga berpengaruh positif namun tidak signifikan terhadap reputasi. Harga yang ditawarkan oleh pihak bank mendapatkan tanggapan dan persepsi yang bagus dari responden bank BNI kcp. Univ. Jember Responden setuju dengan biaya administrasi yang kecil dan saldo minimal yang rendah. Sehingga dapat disimpulkan bahwa semakin rendah biaya administrasi dan saldo minimal yang diberikan maka akan semakin meningkatkan reputasi bank. Hasil penelitian ini sejalan dengan Cristian (2016), dalam penelitian tersebut dikatakan bahwa semakin rendah saldo minimal yang ditetapkan oleh bank dan biaya administrasi yang kecil, maka semakin meningkat pula reputasi perusahaan dikalangan masyarakat. Menurut Kotler dan Amstrong (2012) konsumen selalu mempertimbangkan harga yang sesuai dengan kualitas dan manfaat produk. Dari kajian empiris dan kajian teori tersebut hasil penelitian ini dapat disimpulkan bahwa harga atau biaya administrasi yang kecil dan saldo minimal yang rendah dapat mempengaruhi reputasi perusahan karena sekarang nasabah sudah bisa menilai sendiri harga mana yang menguntungkan untuk mereka.

\section{Pengaruh Tempat terhadap Reputasi nasabah bank BNI kcp. Univ. Jember}

Berdasarkan hasil analisis yang dilakukan menunjukkan bahwa tempat/lokasi perpengaruh terhadap reputasi namun tidak signifikan. Tempat/lokasi yang strategis, fasilitas yang memadai dan kemudahan dalam transportasi dalam menjangkau sebuah bank membuat para nasabah menjadi lebih mudah dalam 
melakukan transaksi. Penelitian ini didukung oleh Cristian (2016) yang menyatakan bahwa tempat/lokasi berpengaruh terhadap reputasi, karena lokasi yang strategis memudahkan para nasabah untuk datang dan memenuhi kebutuhan. Dalam penelitian tersebut dikatakan bahwa tempat/lokasi yang strategis, fasilitas yang memadai dan kemudahan dalam trasnportasi akan meningkatkan reputasi perusahaan. Menurut Rivai (2012) mengatakan bahwa tempat yang strategis dimana produk yang tersedi untuk memungkinkan konsumen agar dapat dengan mudah memperoleh suatu produk. Berdasarkan kajian empiris, kajian teori dan hasil penelitian dapat disimpulkan bahwa tempat yang strategis, tata ruang yang nyaman, fasilitas yang diberikan dan kemudahan dalam transportasi untuk menjangkau bank membuat para nasabah memberikan kesan yang baik, sehingga bisa mempengaruhi reputasi perusahaan.

\section{Pengaruh Promosi terhadap Reputasi nasabah bank BNI kcp. Univ. Jember}

Berdasarkan dari hasil analisis yang dilakukan menunjukkan bahwa promosi berpengaruh signifikan terhadap reputasi. Promosi yang dilakukan terus menerus oleh pemasar bank secara langsung maupun melalui media sosial memudahkan para nasabah memperoleh informasi berkaitan dengan produk bank, keramaham dari para pegawai bank dan hadiah menarik yang ditawarkan, sehingga produk bank dapat terdistribusi ke semua kalangan masyarakat dan dapat mempengaruhi reputasi bank. Pada tabel pernyataan, responden pun setuju dengan memperoleh informasi di website, keramahan para pegawai dan hadiah menarik yang ditawarkan oleh bank pada promosi tersebut. Hasil penelitian ini mendukung penelitian yang dilakukan oleh Cristian (2016) dan Menurut Kasmir (2012) promosi merupakan salah salu faktor penentu keberhasilan suatu program pemasaran, berapapu kualitas suatu produk bila konsumen belum pernah mendengarnya dan tidak yakin bahwa produk tersebut akana berguna bagi mereka, maka mereka tidak akan pernah membelinya. Berdasarkan kajian teori, kajian empiris dan hasil penelitian ini bisa disimpulkan bahwa promosi yang dilakukan secara terus menerus akan dapat meningkatkan reputasi perusahaan. 
Hasil dari penelitian ini mengidentifikasi bahwa promosi yang dilakukan oleh perusahaan akan menetukan kesuksesan produk yang akan kita tawarkan kepada para nasabah, semakin banyak promosi yang dilakukan maka masyarakat semakin menganal produk kita dan sesuai dengan apa yang mereka inginkan.

\section{Pengaruh Reputasi terhadap Keputusan Menabung nasabah bank BNI kcp. Univ. Jember}

Berdasarkan hasil analisis yang dilakukan menunjukkan bahwa reputasi berpengaruh namun tidak signifikan terhadap keputusan menabung. Hasil penelitian ini mendukung penelitian terdahulu yang dilakukan oleh Virgo (2017) yang menyatakan bahwa terdapat pengaruh yang positif reputasi terhadap keputusan menabung. Menurut Dick dkk (2014) mengatakan bahwa reputasi perusahaan adalah bentuk kepercayaan pelanggan terhadap produk atau jasa dari perusahaan yang bersangktan sehingga akan mempengaruhi pelanggan dalam menuntukan pilihan. Berdasarkan kajian empiris, kajian teori dan hasil penelitian ini dapat disimpulkan bahwa reputasi dapat mempengaruhi keputusan nasabah dalam menabung, jika reputasi bank sangat baik di kalangan masyarakat. Hasil penelitian ini mengidentifikasi bahwa reputasi perusahan adalah bentuk kepercayaan pelanggan terhadap produk atau jasa sehingga akan mempengaruhi pelanggan dalam menentukan pilihan. Berdasarkan observasi dan penyebaran kuesioner kepada responden dari tiga item pernyataan, memperoleh tanggapan yang baik dan responden setuju dengan reputasi bank yang memiliki nama baik dan dikenal luas dikalangan masyarakat, sehingga reputasi mempengaruhi keputusan menabung.

\section{Pengaruh Produk terhadap Keputusan Menabung nasabah bank BNI}

\section{kcp. Univ. Jember}

Berdasarkan hasil penelitian yang dilakukan menunjukkan bahwa produk berpengaruh terhadap keputusan menabung. Produk dari bank BNI kcp. Univ. Jember yang produk beraneka ragam, pemberian informasi yang sesuai keinginan dan variasi produk menjadikan salah satu alasan nasabah untuk memutuskan menabung di bank tersebut. Pada tabel pernyataan, tanggapan responden terhadap 
produk bank cukup bagus, dan responden merasa mantap untuk menabungkan uangnya di bank BNI kcp. Univ. Jember dapat diartikan bahwa produk mempengaruhi keputusan menabung. Menurut Kotler (2009) dalam strategi pemasaran yang perlu diperhatikan pertama kali adalah strategi produk. Sehingga produk merupakan hal yang penting karena tanpa adanya produk maka strategi pemasaran lainnya tidak dapat dilakukan. Penelitian ini mendukung penelitian yang dilakukan oleh Sa'adah (2010), menyebutkan bahwa produk berpengaruh signifikan terhadap keputusan pembalian. Hal ini sejalan dengan penelitian yang dilakukan oleh Natalia (2011), Erina (2015), Riza (2016), Aisyah (2016), dan Margarehta (2016) disebutkan bahwa produk berpengaruh terhadap keputusan menabung. Berdasarkan kajian teori, kajian empiris dan hasil penelitian ini dapat disimpulkan bahwa produk terhadap keputusan menabung.

\section{Pengaruh Harga terhadap Keputusan Menabung nasabah bank BNI kcp. Univ. Jember}

Berdasarkan dari hasil analisis yang dilakukan menunjukkan bahwa harga berpengaruh signifikan terhadap keputusan menabung. Hal ini ditunjukan dengan hasil dari observasi, wawancara dan kuesioner yang disebar oleh peneliti, banyak responden berpendapat bahwa harga sangat penting dalam pengambilan keputusan untuk menabung, biaya administari yang kecil tiap bulannya dan saldo minimal waktu pembukaan pertama rekening membuat responden tertarik untuk bergabung menjadi nasabah bank BNI kcp. Univ Jember. Penelitian ini mendukung penelitian sebelumnya yang dilakukan oleh Kurnianto (2013) yang menyebutkan bahwa harga berpengaruh siginifkan terhadap keputusan menabung. Hal ini sejalan dengan penelitian yang dilakukan oleh Sa'adah (2010), , Erina (2015) dan Margaretha (2016), dalam hasil penelitiannya adalah harga berpengaruh terhadap keputusan menabung. Menurut Swastha dan Irawan (2008), harga adalah jumlah uang yang dibutuhkan untuk mendapatkan sejumlah kombinasi dari produk dan pelayanannya. Dapar diartikan bahwa harga merupakan sejumlah uang yang harus dikeluarkan oleh nasabah untuk mendapatkan manfaat dari suatu produk dan jasa. Berdasarkan kajian empiris, kajian teori dan penelitian dapat disimpulkan bahwa harga 
mempengaruhi keputusan menabung.

\section{Pengaruh Tempat/Lokasi terhadap Keputusan Menabung nasabah bank BNI kcp. Univ. Jember}

Berdasarkan hasil analisa yang dilakukan menunjukkan bahwa tempat/lokasi tidak berpengaruh signifikan terhadap keputusan menabung. Hal ini bisa terjadi dikarenakan adanya kemungkinan tempat/lokasi bank belum cukup besar sedangkan nasabah bank BNI kcp. Univ. Jember cukup banyak mengingat bank juga bekerjasama dengan Universitas Jember, apalagi kalau sudah masa mahasiswa untuk pembayaran ukt banyak mahasiswa lebih memilih melakukan pembayaran di BNI kcp. Univ. Jember daripada BNI Cabang sehingga banyak nasabah umum yang harus menunggu cukup lama. Hasil penelitian ini tidak sejalan dengan penelitian yang dilakukan oleh Riza (2016) yang menyatakan bahwa tempat/lokasi berpengaruh terhadap keputusan menabung. Begitu juga dengan penelitian yang dilakukan oleh Sa,adah (2010), Erina (2015), dan Margaretha (2016) yang menyatakan bahwa tempat/lokasi berpengaruh terhadap keputusan menabung. Menurut Kasmir (2008) Lokasi suatu bank akan mempengaruhi kelancaran dari usaha perbankan. Penentuan lokasi suatu cabang bank merupakan salah satu kebijakan yang sangat penting. Bank yang terletak dalam lokasi yang strategis sangat memudahkan nasabah dalam berurusan dengan bank. Berdasarkan kajian empiris, kajian toeri dan hasil penelitian dapat disimpulkan bahwa tempat/lokasi dapat mempengaruhi keputusan menabung nasabah.

\section{Pengaruh Promosi terhadap Keputusan Menabung nasabah bank BNI}

\section{kcp. Univ. Jember}

Berdasarkah hasil analisis yang telah dilakukan menunjukkan promosi berpengaruh signifikan terhadap keputusan menabung, bahkan pengaruhnya lebih besar dari pada variabel lainnya. Pada tabel pertanyaan rata-rata responden mantap menabung karena promosi yang ditawarkan menarik dan responden merespon dengan baik iklan yang ditawarkan bank. Hal ini sejalan dengan penelitisn ysng dilakukan oleh Aisyah (2016) dan Mustikawati (2013), yang menyatakan bahwa promosi berpengaruh terhadap keputusan menabung. Hal ini sejalan dengan 
penelitian yang dilakukan oleh Sa'adah (2010), Natalia (2011), Kurnianto (2013), Erina (2015), Riza (2016), dan Margaretha (2016) dalam hasil penelitiannya promosi berpengaruh terhadap keputusan manabung. Menurut Kasmir (2008) dengan nasabah mengingat produk tabungan maka nasabah akan mengetahui karakteristik dan keunggulan dari produk, hal ini secara tidak langsung akan mempengaruhi nasabah untuk menyimpan dananya ada pada akhirnya nanti kegiatan promosi ini akan meningkatkan citra merk dari produk. Berdasarkan kajian empiris, kajian teori dan hasil penelitian dapat disimpulkan bahwa promosi bisa mempengaruhi keputusan manabung.

\section{Pengaruh Produk terhadap Keputusan Menabung melalui Reputasi nasabah bank BNI kcp. Univ. Jember}

Berdasarkan hasil dari perhitungan pengaruh tidak langsung tabel 3 yang dilakukan menunjukkan bahwa reputasi bukan sebagai variabel intervening untuk variabel produk terhadap keputusan menabung, sehingga dapat diambil kesimpulan bahwa reputasi tidak mempengaruhi keputusan menabung dalam membeli suatu produk. Meskipun produk beraneka ragam, informasi yang di sampaikan sudah sesuai dengan keinginan nasabah dan variasi produk bank yang semakin baik namun ternyata belum mampu meningkatkan reputasi dari bank BNI kcp. Univ. Jember dan reputasinya tidak mempengaruhi nasabah dalam mengambil keputusan untuk menabung di bank. Hal ini tidak sesuai dengan teori yang dikatan oleh Kotler (2009) yang menyatakan bahwa produk mampu membangun reputasi perusahan yang bisa mempertahankan keputusan pembelian konsumen terhadap sebuah produk yang ditawarkan.

\section{Pengaruh Harga terhadap Keputusan Menabung melalui Reputasi nasabah bank BNI kcp. Univ. Jember}

Berdasarkan hasil dari perhitungan pengaruh tidak langsung tabel 3 yang telah dilakukan menunjukkan bahwa reputasi bukan sebagai variabel interveing untuk variabel harga terhadap keputusan menabung, sehingga dapat disimpulkan bahwa reputasi tidak mempengaruhi keputusan manabung dalam melihat sebuah 
harga produk. Hal ini tidak sesuai dengan teori yang dikatan oleh Kotler (2009) yang menyatakan bahwa harga mampu membangun reputasi perusahan yang bisa mempertahankan keputusan pembelian konsumen terhadap sebuah harga. Konsumen selalu mempertimbangkan harga yang sesuai dengan kualitas dan manfaat produk.

\section{Pengaruh Tempat/lokasi terhadap Keputusan Menabung melalui Reputasi nasabah bank BNI kcp. Univ. Jember}

Berdasarakan dari hasil perhitungan pengaruh tidak langsung tabel 3 yang dilakukan menunjukkan bahwa variabel reputasi sebagai variabel intervening untuk variabel tempat/lokasi terhadap keputusan menabung, sehingga dapat diambil kesimpulan bahwa tempat/lokasi dapat mempengaruhi keputusan menabung melalui reputasi. Hal ini sesuai dengan teori yang dikatan oleh Kotler (2009) yang menyatakan bahwa tempat/lokasi mampu membangun reputasi perusahan yang bisa mempertahankan keputusan pembelian konsumen. Berdasarkan dari hasil penelitian dan kajian toeri dapat disimpulkan bahwa tempat/lokasi dapat mempengaruhi keputusan menabung melalui reputasi bank. Jika terbukti sebuah perusahaan memiliki reputasi yang baik maka perusahaan tersebut akan dikenal luas dikalangan masyarakat sehingga menungkatkan loyalitas nasabah kepada bank.

\section{Pengaruh Promosi terhadap Keputusan Menabung melalui Reputasi nasabah bank BNI kcp. Univ. Jember}

Berdasarkan dari hasil perhitungan pengaruh tidak langsung yang dilakukan menunjukkan bahwa reputasi bukan sebagai variabel intervening untuk variabel promosi terhadap keputusan menabung, sehingga dapat disimpulkan bahwa promosi tidak mempengaruhi keputusan menabung melalui reputasi. Seringnya promosi yang dilakukan oleh pihak bank belum mampu untuk membentuk reputasi yang positif di mata masyarakat sehingga belum mampu mempengaruhi nasabah untuk mengambil keputusan dalam menabung. Hal ini tidak sesuai dengan teori yang dikatan oleh Kotler (2009) yang menyatakan bahwa promosi mampu membangun reputasi perusahan yang bisa mempertahankan keputusan pembelian konsumen terhadap sebuah produk yang ditawarkan. Berdasarkan dari hasil penelitian dan

\section{STIE MANDALA JEMBER}


kajian teori bisa disimpulkan bahwa promosi yang dilakukan oleh bagian pemasaran belum mampu meningkatkan reputasi bank.

\section{Kesimpulan}

Berdasarkan hasil penelitian menunjukkan bahwa strategi marketing mix mempunyai pengaruh terhadap keputusan menabung dengan hasil analisis yang dilakukan, dan dapat diambil beberapa kesimpulan antara lain :

1. Berdasarkan hasil analisis yang dilakukan antara marketing mix terhadap reputasi dapat disimpulkan bahwa marketing mix mempengaruhi reputasi bank, hal ini dikarenakan bahwa marketing mix yang meliputi produk, harga, lokasi dan promosi mampu membangu reputasi bank yang bisa mempertahankan nama baik perusahaan di kalangan masyarakat.

2. Berdasarkan hasil analisis yang dilakukan antara reputasi terhadap keputusan menabung, dapat ditarik kesimpulan bahwa reputasi mempengaruhi keputusan menabung. Hal ini di karenakan reputasi menjadi salah satu pegangan penting banyak orang dalam mengambil berbagai macam keputusan penting. Contohnya nasabah membuat keputusan untuk menabungkan uangnya di bank dengan mmemilih produk yang sesuai dengan keinginan dan kebutuhan.

3. Berdasarakan hasil analisa yang telah dilakukan antara marketing mix terhadap keputusan menabung, disimpulkan bahwa produk, harga dan promosi berpengaruh terhadap keputusan menabung. Sedangkan untuk tempat/lokasi berpengaruh negatif terhadap keputusan menabung, hal ini dikarenakan dalam menentukan menabung atau tidaknya para nasabah belum tentu dikarenakan oleh lokasi/tempat yang strategis.

4. Dari hasil uji analisis jalur yang bertujuan mengukur kemampuan variabel reputasi untuk menjadi variabel intervening keputusan menabung. Hasil analisis menyebutkan bahwa reputasi hanya mampu menjadi variabel intervening atas variabel tempat/lokasi terhadap keputusan menabung, karena nilai inderect (pengaruh tidak langsung) lebih besar daripada nilai direct 
(pengaruh langsung).

\section{Implikasi}

Hasil penelitian ini menunjukkan bahwa variabel reputasi berpengaruh terhadap keputusan menabung, hal ini menunjukkan bahwa reputasi suatu perusahaan sangat penting dimata masyarakat, jika reputasi perusahaan kurang baik maka akan menurukan pamor perusahaan itu sendiri begitu juga sebalikanya, jika perusahaan reputasi sudah sangat baik maka para akan menumbuhkan rasa loyalitas yang tinggi dan akan merekomendasikannya kepada pihak lain.

1) Variabel produk berpengaruh signifikan terhadap variabel reputasi dan keputusan menabung, dapat disimpulkan bahwa produk yang ditawarkan oleh perusahaan sudah sesuia dengan keinginan para nasabah bank BNI kcp. Univ jember. Namun produk tidak berpengaruh terhadap keputusan menabung melalui variabel reputasi sebagai variabel interveningnya. Sehingga dapat disimpulkan bahwa meskipun kualitas produk dan varian produk yang beragam, ternyata belum mampu meningkatkan reputasi perusahaan bank BNI KCP. Univ Jember yang juga mempengaruhi keputusan menabung. Oleh karena itu perusahaan dapat lebih meningkatkan lagi kualitas produk ynag ditawarkan, jika sebuah produk mempunyai ciri khas yang membedakanya dari produk lain, produk tersebut akan diingat oleh para nasabah.

2) Variabel harga memiliki pengaruh yang positif terhadap reputasi dan keputusan menabung. Hal ini berarti perusahaan sudah memberikan harga yang bersaing dengan perusahaan lain untuk menungkatkan mutu dan kualitas dihati masyarakat dengan meminimalkan biaya administrasi perbulannya dan saldo minimal yang diberikan, namun harag tidak berpengaruh terhadap keputusan menabung melalui reputasi sebagai variabel interveningnya. Hal ini berarti harga belum bisa meningkatkan reputasi perusahaan dalam keputusan menabung.

3) Variabel tempat/lokasi berpengaruh terhadap reputasi, namun tidak berpengaruh terhadap keputusan menabung. Hal ini berarti tempat/lokasi

\section{STIE MANDALA JEMBER}


perusahaan yang strategis belum tentu mempengaruhi keputusan manabung nasabah, akan tetapi tempat/lokasi memiliki perngaruh terhadap keputusan menabung melalui reputasi sebagai variabel interveningnya. Sehingga reputasi mampu memediasi variabel tempat/lokasi terhadap keputusan menabung.

4) Variabel promosi terhadap reputasi dan keputusan menabung memiliki pengaruh yang lebih besar daripada variabel yang lain, namun variabel promosi tidak memiliki pengaruh terhadap keputusan menabung melalui reputasi sebagai variabel interveningnya. Hal ini berarti bahwa promosi yang dilakukan oleh perusahaan berhasil untuk mempungaruhi keputusan konsumen untuk membeli suatu produk sesuai dengan keinginan nasabah.

\section{Saran}

1. Berdasarkan hasil penelitian menunjukkan bahwa produk, harga, lokasi dan promosi berpengaruh terhadap reputasi perusahaan. Oleh karena itu, bank BNI diharapkan dapat mempertahakan serta meningkatkan strategi merketing mix secara berkala. Namun bukan berarti tidak mempertimbangkan variabel lain.

2. Dari data yang ada kuputusan menabung di bank BNI sangat baik, akan tetapi pihak perusahaan harus terus mengadakan evaluasi terhadap tingkat kepentingan nasabah, karena nasabah tidak dapat mengungkapkan secara jelas apa yang mereka inginkan dari jasa bank, tetapi mereka dapat menceritakan masalah-masalah yang mnimpa mereka kerena menggunakan jasa bank.

3. Pihak bank harus selalu meningkatkan kemampuannya dalam menyediakan jasa yang dimilikinya sehingga nasabah memiliki berbagai pilihan, terutama pilihan lokasi penyediaan jasa tersebut agar memudahkan nasabah untuk menjangkaunya dan juga sebagai peningkatan kualitas jasa itu sendiri.

4. Bagi peneliti selanjutnya disarankan menggunakan metode pemilihan sampel yang berbeda sehingga dapat diperoleh hasil yang lebih baik serta perlu 
mengkaji ulang hasil penelitian pada periode pengamatan dan teknik analisa yang berbeda, guna menguji kosistensi dari hasil penelitian ini sehingga dapat memperbaiki kekurangan-kekurangan yang ada.

\section{DAFTAR PUSTAKA}

Alma, Buchari. "Manajemen Pemasaran dan Pemasaran Jasa”. Bandung : Alfabeta 2014

Chistina, Margaretha. Sekoah Tinngi Ekonomi Perbanas Surabaya, "Pengaruh Pemasaran Jasa Terhadap Keputusan Nasabah Menabung Pada PT. Bank Mandiri (Persero) di Surabaya”. Jurnal 2016

Christian, "Pengaruh Bauran Pemasaran Terhadap Kepercayaan Pasien Serta Dampaknya pada Reputasi Puskesmas Pada Pasien Poliklinik Umum Puskesmas Puter Dinas Kesehatan Kota Bandung”. Jurnal 2016

Dendawijaya, Manajemen Perbankan, cetakan ketiga. Jakarta : Ghalia Indonesia 2009

Ferdinan, Augusty. “Metode Penelitian Manajemen”. Edisi 5, Undip 2014

Ghazali, Imam “Aplikasi Anaisis Multivariate dengan Program SPSS”. Badan Penerbit Universitas Diponegoro, Semarang 2016

Kasmir, Bank dan dan Lembaga Keuangan. Jakarta : PT. Raja Grafindo Persada. 2012

Kasmir, Kewirausahaan, Jakarta : Rajawali. 2014

Kasmir, manajemen perbankan. Jakarta : kencana 2008

Kasmir, pemasaran bank. Jakarta : kencana 2008

Kotler dan Amstrong, Prinsip-Prinsip Pemasaran. Jakarta : Erlangga 2008

Kotler dan Keller, Manajemen Pemasaran. Jakarta : Erlangga 2012

Kotler, Philip, Merketing. Jakarta : Erlangga 2009

Kurnianto, Eman "Pengaruh Marketing Mix Terhadap Keputusan Costumer 
Menabung di Taheta PT. Bank Pembangunan Daerah Kalimantan Tengah Cabang Tamiang Layan”. Jurnal 2013

Mc Daniel, Pemasaran. Salemba Empat Jakarta, 2010

Mustikawati, Rr. Indah Fakultas Ekonomi Universitas Negeri Yogyakarta, "Pengaruh Persepsi Nasabah Tentang Suku Bunga, Promosi dan Kualitas Pelayanan Terhadap Minat Menabung Nasabah” Jurnal nominal vol 2 no 1,2013

Natalia, irwanda. Fakultas Ekonomi Universitas Hasanudin, "Pengaruh Marketing Mix Terhadap Keputusan Konsumen yang menabung pada PT. Bank Mandiri Cabang Makasar Kartini”. Jurnal 2011

Rivai, Veithzal, "Islamic Marketing (Membangun dan mengembangkan Bisnis dengan Praktik Marketing Rasullah saw)”. Gramedia Pustaka Utama, Jakarta, 2012

Sa'adah, Nailus. Fakultas Syariah dan Hukum Universitas Syarif Hidayatullah, "Analisis Terhadap Alasan Masyarakat Untuk Menjadi Nasabah BNI Syariah Ditinjau dari Perspektif Markeitng Mix”. Jurnal 2010

Setyani, Erina. Fakultas Ekonomi dan Bisnis Islam Universitas Islam Negeri Walisongo, "Pengaruh Marketing Mix Terhadap Keputusan pembelian Konsumen di Toko Alat Tulis Hadi Sutrisno Putra 2 Limpung. Jurnal 2015

Simamora, Virgo. Fakultas Ekonomi dan Bisnis Universitas 17 Agustus 1945 Jakarta. "Pengaruh Reputasi Perusahaan Terhadap Keputusan Pembelian Dengan Lepercayaan Konsumen Sebagai Variabel Intervening”. Jurnal 2017

Sugiyono, "Metode Penelitian Kuantitatif dan Kualitatif, CV. Alfabeta, Bandung 2017

Sugiyono, "Metode Penelitian Kuantitatif Kualitatif dan R\&D”. Alfabeta, Bandung, 2014

Sugiyono, "Metode Penelitian Kuantitatif Kualitatif dan R\&D". Alfabeta, Bandung, 2015

Tjiptono, Fandy, “Pemasaran Jasa, Prinsip, Penerapan dan Penelitian”. Andi Offset, Yogyakarta, 2014

Tjiptono, Fandy, “Strategi Pemasaran”. Andi Offset, Yogyakarta, 2010 
Ulfa, Rizka. Fakultas Ekonomi dan Bisnis Islam Institut Agama Islam Negari Salatiga, "Pengaruh Marketing Mix Terhadap Keputusan Menjadi Nasabah Tabungan IB Muamalat Di Bank Muamalat KCP Salatiga” Jurnal, 2016

Van Oostenbrugge, Steve J. "Costumer Satisfaction And Corporate Reputasi : A Correlation Study, Capella University, ProQuest, Umi Dissertation Publishing, 2013 